\title{
Adsorption of arsenate on soils. Part 1: Laboratory batch experiments using 16 Chinese soils with different physiochemical properties
}

\author{
Wei Jiang ${ }^{a}$, Shuzhen Zhang ${ }^{a, *}$, Xiao-quan Shan ${ }^{a}$, Muhua Feng ${ }^{a}$, \\ Yong-Guan Zhu ${ }^{\text {a }}$, Ron G. McLaren ${ }^{b}$ \\ ${ }^{a}$ State Key Laboratory of Environmental Chemistry and Ecotoxicology, Research Center for Eco-Environmental Sciences, \\ Chinese Academy of Sciences, P.O. Box 2871, Beijing 100085, China \\ ${ }^{\mathrm{b}}$ Soil and Physical Sciences Group, Agriculture and Life Sciences Division, P.O. Box 84, Lincoln University, \\ Canterbury, New Zealand
}

Received 30 April 2004; accepted 22 March 2005

The Langmuir two-surface equation fits arsenate adsorption onto soils.

\begin{abstract}
Laboratory batch experiments were carried out to study the adsorption of arsenate on 16 Chinese soils with different physicochemical properties. Wide differences in arsenate adsorption were observed, and the Jiangxi and Hubei soils were more effective sorbents for arsenate than other soils. The Langmuir one-surface and two-surface equations were used to model the arsenate adsorption data. Except for the Jiangxi and Hubei soils, the Langmuir one-surface equation gave reasonably good fits to the arsenate adsorption data. However, the Langmuir two-surface equation generally provided a better fit than the Langmuir onesurface equation. For soils with relative high organic matter (OM), dissolved organic carbon (DOC) or extractable phosphate, the Langmuir one-surface and two-surface equations described the adsorption isotherms similarly. In contrast, for soils with relatively low contents of OM, DOC or extractable phosphate, the Langmuir two-surface equation gave the better fit to the arsenate adsorption data.
\end{abstract}

(C) 2005 Elsevier Ltd. All rights reserved.

Keywords: Arsenate adsorption; Langmuir equation; Soil

\section{Introduction}

Arsenic-contaminated soils exert a great threat to human health due to their high potential to pollute surface and ground waters, or by introducing arsenic into the food chain through plant uptake. The mobility,

\footnotetext{
* Corresponding author. Tel.: +86 10 6849683; fax: +86 10 62923563.

E-mail address: szzhang@mail.rcees.ac.cn (S. Zhang).
}

toxicity and bioavailability of arsenic in soil are largely controlled by the adsorption of arsenic by the soil. Hence, in order to elucidate the fate of arsenic in soil, it is important to study the adsorption process.

Much work has been devoted to the study of arsenate adsorption on individual soil minerals, for example on iron oxides (Pierce and Moore, 1982; Fendorf et al., 1997), aluminium oxides (Anderson et al., 1975; Xu et al., 1991), manganese oxides (Oscarson et al., 1983), phyllosilicate clay minerals (Frost and Griffin, 1977; Goldberg and Glaubig, 1988), and on calcium carbonate 
(Goldberg and Glaubig, 1988). However, although there are some studies of arsenate adsorption on intact soils (e.g. Smith et al., 2002; Violante and Pigna, 2002), they are relatively few in number. Soils are heterogeneous complexes of organic matter, metal oxides, clay minerals and microorganisms, with diverse structures. In addition, soil micropores and macropores have an impact on the adsorption of metals or metalloids. Therefore, individual soil components cannot truly model soils (Harter and Naidu, 2001), and adsorption of metals or metalloids is best studied using actual soils as adsorbents.

When studying adsorption of metals or metalloids by soils, various adsorption-isotherm equations have been widely used to compare the adsorption by different soils; most commonly the Freundlich and Langmuir equations. Of these two equations, the Langmuir equation often provides the better fit to metal and metalloid adsorption data, and enables the calculation of the maximum adsorption capacity and a parameter related to bonding energy. One basic assumption underlying the Langmuir equation is that all the adsorption sites are uniform. However, it seems unlikely that all adsorption sites on soil surfaces have the same binding energy for a particular metal or metalloid, therefore the Langmuir equation must be used with caution. Previous studies have shown that in some cases when adsorption data is plotted using the linear form of the Langmuir equation, the resulting plot can be divided into two straight line portions with different gradients. It is assumed that this results from the presence of two different types of adsorption site (e.g. Syers et al., 1973). To model this situation, the Langmuir two-surface equation was developed, which assumes that adsorption occurs on both relatively high- and low-energy surface adsorption sites. The Langmuir two-surface equation has been successively used to describe phosphate adsorption on soils (Holford et al., 1974; Holford and Mattingly, 1976; Melamed et al., 1995; Sui and Thompson, 2000). While the chemical properties of phosphate are analogous to arsenate, it is unknown whether the Langmuir twosurface could also model arsenate adsorption on soil better than the Langmuir one-surface model.

In this study, 16 Chinese soils with various physical and chemical properties were used to investigate arsenate adsorption on soil. The Langmuir one-surface and two-surface equations were compared for the best fit of the resulting arsenate adsorption data.

\section{Materials and methods}

\subsection{Soils}

Sixteen surface soil samples $(0-20 \mathrm{~cm})$ were collected from cultivated land in different provinces of China, in areas away from industrial sites. The soils represent typical Chinese soils with different physical and chemical properties. Soil samples were air-dried, homogenized and ground to pass through $1 \mathrm{~mm}$ nylon fibre sieve, and stored for subsequent analysis and experiments.

Soil pH was measured in $0.01 \mathrm{M} \mathrm{CaCl}_{2}$ at $1: 1$ (w:v) soil solution ratio. Cation exchange capacity (CEC) was determined by the method of Rhoades (1982). Organic matter content $(\mathrm{OM})$ was determined by the Walkley-Black's procedure (Nelson and Sommers, 1982). Dissolved organic carbon (DOC) was determined by total organic carbon analyzer (Phoenix 8000, TekmarDohrmann co., U.S.A.) after shaking $1 \mathrm{~g}$ of soil in $30 \mathrm{ml}$ deionized water for $24 \mathrm{~h}$, centrifuging at $7200 \times \mathrm{g}$ for $20 \mathrm{~min}$ and filtering with $0.45 \mu \mathrm{m}$ cellulose nitrate membrane. Amorphous $\mathrm{Fe}, \mathrm{Al}$ and $\mathrm{Mn}$ were extracted by shaking $1 \mathrm{~g}$ of soil in $30 \mathrm{ml}$ of acidified ammonium oxalate buffer $\left(0.175 \mathrm{M}\left(\mathrm{NH}_{4}\right)_{2} \mathrm{C}_{2} \mathrm{H}_{4}+0.1 \mathrm{M} \mathrm{H}_{2} \mathrm{C}_{2} \mathrm{O}_{4}\right.$, $\mathrm{pH}$ 3.0) for $2 \mathrm{~h}$ (Loeppert and Inskeep, 1996). Citratedithionite (CD) extractable $\mathrm{Fe}, \mathrm{Al}$ and $\mathrm{Mn}$ were determined by Manning and Goldberg's procedure (1997). Sodium bicarbonate extractable P was determined using the method of Olsen et al. (1954). Concentrations of $\mathrm{Fe}, \mathrm{Al}, \mathrm{Mn}$ and $\mathrm{P}$ were determined by inductively coupled plasma atomic emission spectrometry (ICP-AES, OPTIMA2000DV, Perkin Elmer). Soil texture was obtained by Laser Particle Analyzer (Malvern Mastersizer 2000) after destroying the organic matter by $30 \% \mathrm{H}_{2} \mathrm{O}_{2}$ and dispersing the aggregates in soil by sodium hexametaphosphate (Day, 1965). Total arsenic in soil was determined by hydride generation atomic fluorescence spectrometry (HG-AFS, AFS-610A model atomic fluorescence spectrophotometer, Beijing BRAIC Instrumental Company, Beijing, China) after digestion of soils with $3: 1$ (v:v) $\mathrm{HNO}_{3}: \mathrm{HClO}_{4}$. All measurements were repeated in triplicate. The soil properties are summarized in Table 1.

\subsection{Adsorption experiments}

A stock solution, containing $1000 \mathrm{mg} \mathrm{As} 1^{-1}$, was made by dissolving $2.831 \mathrm{~g} \mathrm{Na}_{3} \mathrm{AsO}_{4} \cdot 12 \mathrm{H}_{2} \mathrm{O}$ (analytical reagent grade, Beijing Chemicals, China) in a $100 \mathrm{ml}$ beaker in dilute nitric acid, transferred to $500 \mathrm{ml}$ of volumetric flask and diluted to the mark with deionized water, from which all working standards and initial solutions for arsenate adsorption isotherms were prepared by a serial dilution with deionized water. The adsorption solution was adjusted to the same $\mathrm{pH}$ as the soil $\mathrm{pH}$ before adsorption was determined. A batch equilibration method was used for adsorption of arsenate. The $\mathrm{pH}$ of the soil suspensions did not show any obvious change during the experimental period. In all adsorption experiments $1 \mathrm{~g}$ of soil and $20 \mathrm{ml}$ of $0.02 \mathrm{M} \mathrm{NaNO} \mathrm{Nan}_{3}$ containing different initial arsenate 
Table 1

Location, classification and properties of the soils

\begin{tabular}{|c|c|c|c|c|c|c|c|c|c|c|c|c|c|c|c|}
\hline \multirow[t]{2}{*}{ Classification } & \multirow[t]{2}{*}{$\mathrm{pH}$} & \multirow{2}{*}{$\begin{array}{l}\text { CEC } \\
\left(\mathrm{cmol} \mathrm{kg}^{-1}\right)\end{array}$} & \multirow{2}{*}{$\begin{array}{l}\mathrm{OM} \\
(\%)\end{array}$} & \multirow{2}{*}{$\begin{array}{l}\text { DOC } \\
\left(\mathrm{mg} \mathrm{kg}^{-1}\right)\end{array}$} & \multirow{2}{*}{$\begin{array}{l}\mathrm{P} \\
\left(\mathrm{mg} \mathrm{kg}^{-1}\right)\end{array}$} & \multirow{2}{*}{$\begin{array}{l}\text { As } \\
\left(\mathrm{mg} \mathrm{kg}^{-1}\right)\end{array}$} & \multirow{2}{*}{$\begin{array}{l}\mathrm{Fe}_{\mathrm{OX}} \\
\left(\mathrm{mg} \mathrm{kg}^{-1}\right)\end{array}$} & \multirow{2}{*}{$\begin{array}{l}\mathrm{Al}_{\mathrm{OX}} \\
\left(\mathrm{mg} \mathrm{kg}^{-1}\right)\end{array}$} & \multirow{2}{*}{$\begin{array}{l}\mathrm{Mn}_{\mathrm{OX}} \\
\left(\mathrm{mg} \mathrm{kg}^{-1}\right)\end{array}$} & \multirow{2}{*}{$\begin{array}{l}\mathrm{Fe}_{\mathrm{CD}} \\
\left(\mathrm{mg} \mathrm{kg}^{-1}\right)\end{array}$} & \multirow{2}{*}{$\begin{array}{l}\mathrm{Al}_{\mathrm{CD}} \\
\left(\mathrm{mg} \mathrm{kg}^{-1}\right)\end{array}$} & \multirow{2}{*}{$\begin{array}{l}\mathrm{Mn}_{\mathrm{CD}} \\
\left(\mathrm{mg} \mathrm{kg}^{-1}\right)\end{array}$} & \multicolumn{3}{|c|}{ Texture $\%(\mathrm{v} / \mathrm{v})$} \\
\hline & & & & & & & & & & & & & Clay & Silt & Sand \\
\hline \multicolumn{16}{|l|}{ Alfisols } \\
\hline Beijing & 6.9 & 15.7 & 1.35 & 438 & 26.5 & 8.3 & 984 & 608 & 263 & 2882 & 689 & 261 & 23.0 & 44.8 & 32.2 \\
\hline Jiangsu & 6.4 & 22.3 & 0.68 & 526 & 143.4 & 4.6 & 1231 & 429 & 253 & 2920 & 345 & 261 & 21.4 & 65.5 & 13.1 \\
\hline Shanxi & 7.3 & 21.9 & 4.12 & 279 & 39.8 & 9.8 & 558 & 772 & 220 & 3435 & 718 & 288 & 29.6 & 52.3 & 18.1 \\
\hline Shandong & 6.8 & 18.0 & 0.98 & 257 & 29.9 & 7.6 & 1158 & 569 & 845 & 3385 & 730 & 892 & 22.4 & 55.6 & 22.0 \\
\hline Anhui & 5.2 & 25.0 & 2.09 & 658 & 158.3 & 8.6 & 1305 & 848 & 183 & 5548 & 1254 & 269 & 32.2 & 59.1 & 8.7 \\
\hline Jilin & 5.7 & 14.0 & 2.56 & 569 & 89.5 & 4.5 & 2711 & 1578 & 739 & 3965 & 1827 & 706 & 34.6 & 45.0 & 20.4 \\
\hline Hubei & 6.7 & 22.8 & 0.92 & 274 & 27.0 & 8.3 & 4742 & 693 & 246 & 9219 & 784 & 430 & 26.5 & 51.3 & 22.2 \\
\hline \multicolumn{16}{|l|}{ Aridisols } \\
\hline Xinjiang & 7.4 & 74.0 & 0.90 & 384 & 49.5 & 4.9 & 519 & 190 & 99 & 2024 & 298 & 181 & 10.8 & 34.0 & 55.2 \\
\hline Gansu & 6.6 & 41.2 & 0.96 & 370 & 28.8 & 10.5 & 607 & 452 & 160 & 2802 & 471 & 269 & 18.7 & 55.7 & 25.6 \\
\hline \multicolumn{16}{|l|}{ Inceptisols } \\
\hline Chengdu & 6.5 & 42.6 & 1.03 & 360 & 8.2 & 8.3 & 1012 & 579 & 420 & 4681 & 987 & 447 & 19.8 & 48.0 & 32.2 \\
\hline \multicolumn{16}{|l|}{ Mollisols } \\
\hline Neimenggu & 6.3 & 56.8 & 3.81 & 243 & 25.3 & 9.9 & 658 & 810 & 168 & 2846 & 760 & 214 & 26.2 & 45.0 & 28.8 \\
\hline Heilongjiang & 7.4 & 20.2 & 6.86 & 891 & 338.9 & 8.7 & 2877 & 1366 & 237 & 4664 & 1246 & 309 & 39.6 & 56.0 & 4.4 \\
\hline \multicolumn{16}{|l|}{ Ultisols } \\
\hline Fujian & 6.1 & 5.1 & 1.81 & 420 & 39.0 & 1.6 & 1989 & 455 & 43 & 4432 & 597 & 64 & 29.6 & 33.7 & 36.7 \\
\hline Yunnan & 6.6 & 15.5 & 2.23 & 494 & 114.3 & 9.3 & 3122 & 1341 & 389 & 6888 & 1530 & 403 & 31.9 & 29.1 & 39.0 \\
\hline Guizhou & 6.3 & 51.3 & 6.76 & 495 & 97.8 & 17.1 & 4289 & 1390 & 480 & 6193 & 1291 & 553 & 37.2 & 32.8 & 30.0 \\
\hline Jiangxi & 4.7 & 14.2 & 0.80 & 226 & 5.7 & 9.4 & 339 & 819 & 19 & 8301 & 1850 & 70 & 45.6 & 23.5 & 30.9 \\
\hline
\end{tabular}

$\mathrm{Fe}_{\mathrm{OX}}, \mathrm{Al}_{\mathrm{OX}}, \mathrm{Mn}_{\mathrm{OX}}$ : Amorphous $\mathrm{Fe}, \mathrm{Al}$ and $\mathrm{Mn}$ extracted by acidified ammonium oxalate buffer. $\mathrm{Fe}_{\mathrm{CD}}, \mathrm{Al}_{\mathrm{CD}}, \mathrm{Mn}_{\mathrm{CD}}$ : citrate-dithionite $(\mathrm{CD})$ extractable $\mathrm{Fe}, \mathrm{Al}$ and $\mathrm{Mn}$. 
concentrations were used. After shaking for $24 \mathrm{~h}$ $\left(21 \pm 1{ }^{\circ} \mathrm{C}\right)$ and centrifuging at $7200 \times \mathrm{g}$, the $\mathrm{As}(\mathrm{v})$ was reduced by $10 \mathrm{~g}^{-1}$ thiourea and diluted with $10 \%$ high purity $\mathrm{HCl}$. Arsenic concentrations were determined by HG-AFS. The amount of arsenic adsorbed was calculated by the difference between the initial and final concentrations of arsenic in the equilibrium solution. Adsorption determinations were performed in triplicate.

\subsection{Adsorption equations}

Langmuir one-surface and Langmuir two-surface equations were used to describe the adsorption of arsenate on soil.

The Langmuir one-surface equation is:

$q=K c M /(1+K c)$

where $q$ is the adsorbed arsenate, $\mathrm{mg} \mathrm{kg}^{-1} ; c$ is the equilibrium concentration of arsenate, $\mathrm{mg}^{-1} ; M$ is the maximum capacity of arsenate adsorption, $\mathrm{mg} \mathrm{kg}^{-1}$; $K$ is the adsorption equilibrium constant related to bonding energy, $1 \mathrm{mg}^{-1}$.

The Langmuir two-surface equation is as follows:

$q=K_{1} M_{1} c /\left(1+K_{1} c\right)+K_{2} M_{2} c /\left(1+K_{2} c\right)$

where $M_{1}$ and $K_{1}$ represent the adsorption maximum and adsorption equilibrium constant for the low-energy surface and $M_{2}$ and $K_{2}$ for the high-energy surface. The total adsorption maximum capacity, $M$, is written as

$M=M_{1}+M_{2}$

\subsection{Data analysis}

Fitting of adsorption isotherms, and the calculation of the parameters in Eqs. (1) and (2) were undertaken by nonlinear regression using Origin 7.0. The goodness of the fit of the Langmuir equations was compared by single regression analysis of the actual and predicted As adsorption for each soil (e.g. Mead, 1981).

\section{Results}

\subsection{Soil properties}

The physical and chemical soil properties of the 16 Chinese soils varied widely (Table 1). The soil $\mathrm{pH}$ ranged from 4.70 to 7.44 , the CEC ranged from 5.1 to $74 \mathrm{cmol} \mathrm{kg}^{-1}$, the OM varied from 0.8 to $6.86 \%$, and the DOC from 226 to $891 \mathrm{mg} \mathrm{kg}^{-1}$. Extractable P, Fe, $\mathrm{Al}$ and $\mathrm{Mn}$ also differed greatly between soils. Total arsenic concentrations in the soils ranged from 1.6 to
$17.1 \mathrm{mg} \mathrm{kg}^{-1}$. All of these soils can be considered as uncontaminated soils (Mandal and Suzuki, 2002). On the basis of the particle size distribution, the Xinjiang soil is a sandy-loam, the Gansu, Jiangsu, Hubei and Shandong soils are silt-loams, the Neimenggu, Beijing and Chengdu soils are loams, the Shanxi, Anhui and Heilongjiang soils are silty-clay-loams, the Jilin, Fujian, Yunnan and Guizhou soils are clay-loams, and only the Jiangxi soil is categorised as a clay.

\subsection{Adsorption of arsenate on soils}

Experimental data for arsenate adsorption on all the 16 soils are described in Fig. 1. Near maximum adsorption was attempted in order to obtain better fitting by the adsorption equations. Wide differences in arsenate adsorption were observed among the 16 soils, with adsorption by the Jiangxi and Hubei soils being much higher than for all of the other soils.

\subsection{Comparison between the Langmuir one-surface and Langmuir two-surface equations for fitting arsenate adsorption by soils}

The Langmuir one-surface and Langmuir twosurface equations were both used to fit the adsorption isotherms. The Freundlich equation was also tested but produced poor fits to the adsorption-isotherm data; therefore, no further discussion of this equation is included in this paper. The parameters predicted from the Langmuir equations are shown in Table 2. For the Langmuir one-surface equation, predicted adsorption capacities $(M)$ ranged from a low of $21.99 \mathrm{mg} \mathrm{kg}^{-1}$ for the Xinjiang soil to a high of $524.86 \mathrm{mg} \mathrm{kg}^{-1}$ for the Jiangxi soil. For the Langmuir two-surface equation, predicted adsorption capacities $\left(M_{1}+M_{2}\right)$ ranged from 30.55 to $616.85 \mathrm{mg} \mathrm{kg}^{-1}$. Adsorption capacities predicted from fitting the Langmuir two-surface equation were for some soils the same, or similar to those values predicted from the Langmuir one-surface equation (Table 2). For other soils, particularly the Hubei and Jiangxi soils, adsorption capacities derived from the Langmuir two-surface equation were substantially higher than those derived from the Langmuir one-surface equation (Table 2).

The goodness-of-fit of the two Langmuir models was compared by simple linear regression analysis between the predicted and observed adsorption data (Table 3). The Langmuir one-surface equation predicted arsenate adsorption well for most of the soils, but not for the Jiangxi and Hubei soils, where relatively high standard errors (S.E.) occurred as can be seen in Table 3. The predicted maximum adsorption capacities for these two soils were also greatly underestimated by the Langmuir one-surface equation (Fig. 2). The Langmuir twosurface equation generally fitted arsenate adsorption 


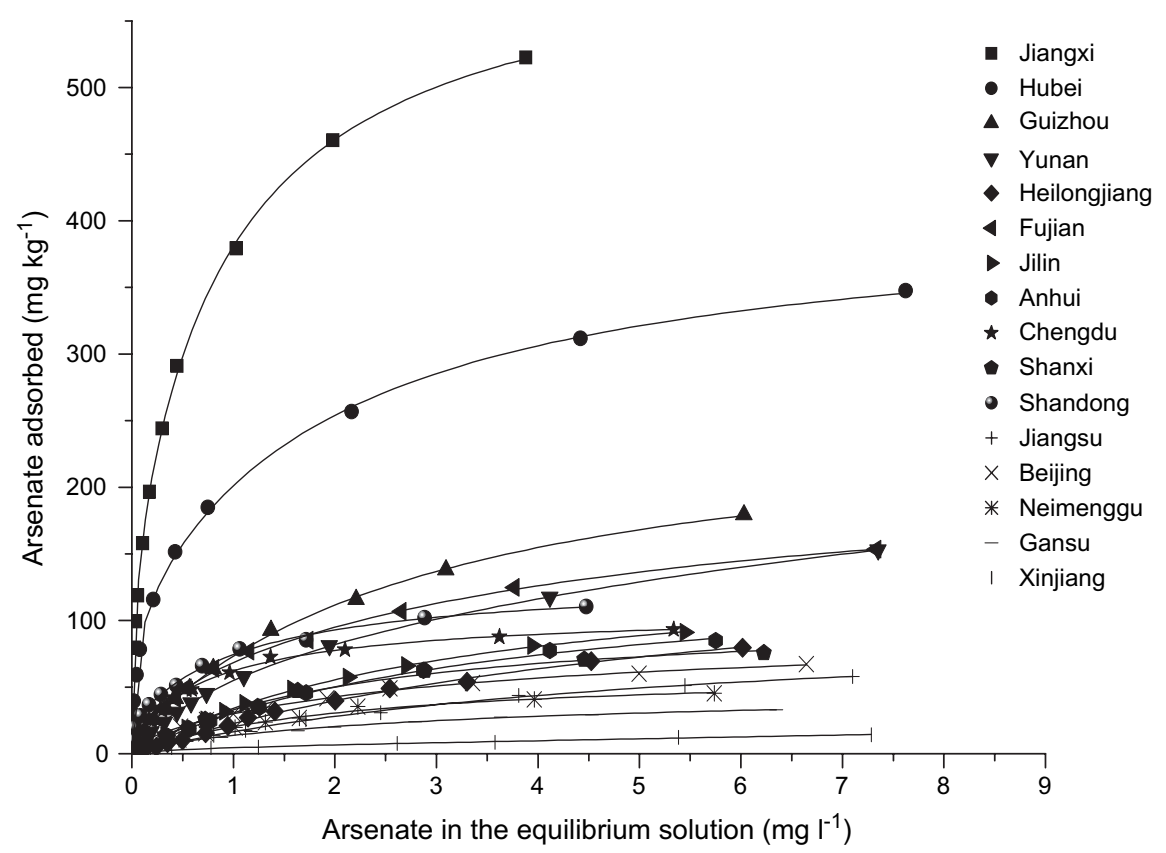

Fig. 1. Adsorption isotherms of arsenate by soils and Langmuir two-surface equation fitting to the experimental data (solid lines).

onto soils more accurately, especially for the Jiangxi and Hubei soils. The coefficients of determination between observed and predicted adsorption for the Langmuir two-surface equation ranged from 0.9924 to 0.9999 , higher values than those obtained using the Langmuir one-surface equation (Table 3).

\section{Discussion}

Why was the Langmuir one-surface equation a good fit for some soils, but not for others? One reason is that the 16 soils have very different physiochemical properties. In general, for soils with relatively high OM, DOC or extractable $\mathrm{P}$, both the Langmuir one-surface and two-surface equations could describe the adsorption isotherms almost equally well. A possible reason is that adsorption sites on the high-energy surface in these soils were already occupied by indigenous phosphate or organic matter as a result of the relatively long residence times for these adsorbates, compared with the freshly added arsenate. Therefore, arsenate adsorption would have occurred predominantly on the low-energy surface. A similar phenomenon was observed for phosphate adsorption (Holford et al., 1974). For phosphate adsorption on soils with high extractable $\mathrm{P}$, the Langmuir two-surface equation would be the same as the Langmuir one-surface equation because the high-energy surface

Table 2

Langmuir one-surface and Langmuir two-surface equation parameters calculated using Nonlinear-Curve-Fitting for adsorption isotherms of 16 soils

\begin{tabular}{|c|c|c|c|c|c|c|}
\hline \multirow[t]{2}{*}{ Soil } & \multicolumn{2}{|c|}{ Langmuir one-surface } & \multicolumn{4}{|c|}{ Langmuir two-surface } \\
\hline & $K\left(1 \mathrm{mg}^{-1}\right)$ & $M\left(\mathrm{mg} \mathrm{kg}^{-1}\right)$ & $K_{1}\left(1 \mathrm{mg}^{-1}\right)$ & $K_{2}\left(1 \mathrm{mg}^{-1}\right)$ & $M_{1}\left(\mathrm{mg} \mathrm{kg}^{-1}\right)$ & $M_{2}\left(\mathrm{mg} \mathrm{kg}^{-1}\right)$ \\
\hline Xinjiang & 0.227 & 21.99 & 0.090 & 2.886 & 27.61 & 2.94 \\
\hline Gansu & 0.469 & 43.25 & 0.292 & 11.005 & 44.96 & 3.95 \\
\hline Neimenggu & 0.475 & 62.90 & 0.475 & - & 62.90 & 0 \\
\hline Beijing & 0.613 & 80.46 & 0.336 & 12.560 & 81.85 & 10.10 \\
\hline Jiangsu & 0.202 & 98.27 & 0.185 & 483.092 & 100.88 & 0.83 \\
\hline Chengdu & 1.813 & 100.28 & 1.099 & 38.462 & 93.23 & 13.74 \\
\hline Shanxi & 0.460 & 104.55 & 0.460 & - & 104.55 & 0 \\
\hline Shandong & 2.262 & 114.80 & 0.889 & 60.314 & 107.97 & 24.04 \\
\hline Anhui & 0.276 & 141.24 & 0.276 & - & 141.24 & 0 \\
\hline Jilin & 0.301 & 147.54 & 0.301 & - & 147.54 & 0 \\
\hline Fujian & 0.674 & 175.55 & 0.211 & 3.172 & 173.22 & 50.41 \\
\hline Heilongjiang & 0.164 & 161.21 & 0.164 & - & 161.21 & 0 \\
\hline Yunnan & 0.368 & 203.53 & 0.072 & 1.066 & 254.33 & 73.45 \\
\hline Guizhou & 0.450 & 241.22 & 0.334 & 7.439 & 249.38 & 12.53 \\
\hline Hubei & 1.746 & 364.87 & 0.383 & 21.612 & 317.29 & 115.97 \\
\hline Jiangxi & 3.458 & 524.86 & 1.026 & 32.541 & 468.86 & 147.99 \\
\hline
\end{tabular}


Table 3

Langmuir one-surface and Langmuir two-surface equations for fitting to the experimental data

\begin{tabular}{|c|c|c|c|c|c|c|c|c|}
\hline \multirow[t]{2}{*}{ Localization } & \multicolumn{4}{|c|}{ Langmuir one-surface } & \multicolumn{4}{|c|}{ Langmuir two-surface } \\
\hline & S.E. & $a$ & $b$ & $R^{2}$ & S.E. & $a$ & $b$ & $R^{2}$ \\
\hline Xinjiang & 0.70 & 0.41 & 0.96 & 0.9878 & 0.50 & 0.01 & 1.00 & 0.9924 \\
\hline Gansu & 1.03 & 1.00 & 0.96 & 0.9928 & 0.62 & 0.00 & 1.00 & 0.9965 \\
\hline Neimenggu & 1.29 & -0.11 & 1.00 & 0.9930 & 1.29 & -0.11 & 1.00 & 0.9930 \\
\hline Beijing & 2.25 & 2.37 & 0.95 & 0.9931 & 0.79 & 0.00 & 1.00 & 0.9986 \\
\hline Jiangsu & 0.81 & 0.39 & 0.99 & 0.9986 & 0.72 & 0.00 & 1.00 & 0.9988 \\
\hline Chengdu & 3.37 & 3.46 & 0.95 & 0.9931 & 1.25 & -0.07 & 1.00 & 0.9985 \\
\hline Shanxi & 2.12 & 0.37 & 0.99 & 0.9944 & 2.12 & 0.37 & 0.99 & 0.9944 \\
\hline Shandong & 6.63 & 6.60 & 0.91 & 0.9813 & 1.98 & 0.70 & 0.99 & 0.9973 \\
\hline Anhui & 1.30 & 0.26 & 1.00 & 0.9983 & 1.30 & 0.26 & 1.00 & 0.9983 \\
\hline Jilin & 0.78 & 0.05 & 1.00 & 0.9993 & 0.78 & 0.05 & 1.00 & 0.9993 \\
\hline Fujian & 5.17 & 3.92 & 0.96 & 0.9915 & 1.99 & 0.49 & 1.00 & 0.9983 \\
\hline Heilongjiang & 1.46 & -0.63 & 1.01 & 0.9972 & 1.46 & -0.63 & 1.01 & 0.9972 \\
\hline Yunnan & 3.27 & 2.11 & 0.98 & 0.9967 & 0.53 & 0.24 & 1.00 & 0.9999 \\
\hline Guizhou & 2.81 & 2.11 & 0.98 & 0.9984 & 1.41 & -0.01 & 1.00 & 0.9994 \\
\hline Hubei & 25.88 & 23.18 & 0.91 & 0.9788 & 4.06 & 1.53 & 0.99 & 0.9992 \\
\hline Jiangxi & 31.14 & 29.11 & 0.92 & 0.9757 & 3.27 & 0.15 & 1.00 & 0.9996 \\
\hline
\end{tabular}

S.E. $=$ standard error of the estimate. $a, b$ and $R^{2}$ are intercept, slope and coefficient of determination of the equation $y=a+b x$, where $y$ is the actual adsorbed quantity and $x$ is the model predicted quantity.

would have been fully saturated with phosphate. In support of this hypothesis, Smith et al. (2002) and Violante et al. (2002) have reported that phosphate decreases the adsorption of arsenate by soils. Previous studies have also demonstrated the competitive effect of DOC and OM on arsenate adsorption (Fontes et al., 1992; Gu et al., 1994).

In contrast, for soils with relatively low contents of $\mathrm{OM}$, DOC or extractable $\mathrm{P}$, both the high-energy and low-energy surface adsorption sites would be available for arsenate adsorption. In this situation, adsorption of arsenate would be unlikely to take place at sites with same binding affinity. Hence the Langmuir two-surface equation describes arsenate adsorption better.

To conclude, the 16 Chinese soils represented different adsorption capacities. The Langmuir onesurface equation could describe model arsenate adsorption on most of the soils. But for soils with low OM,

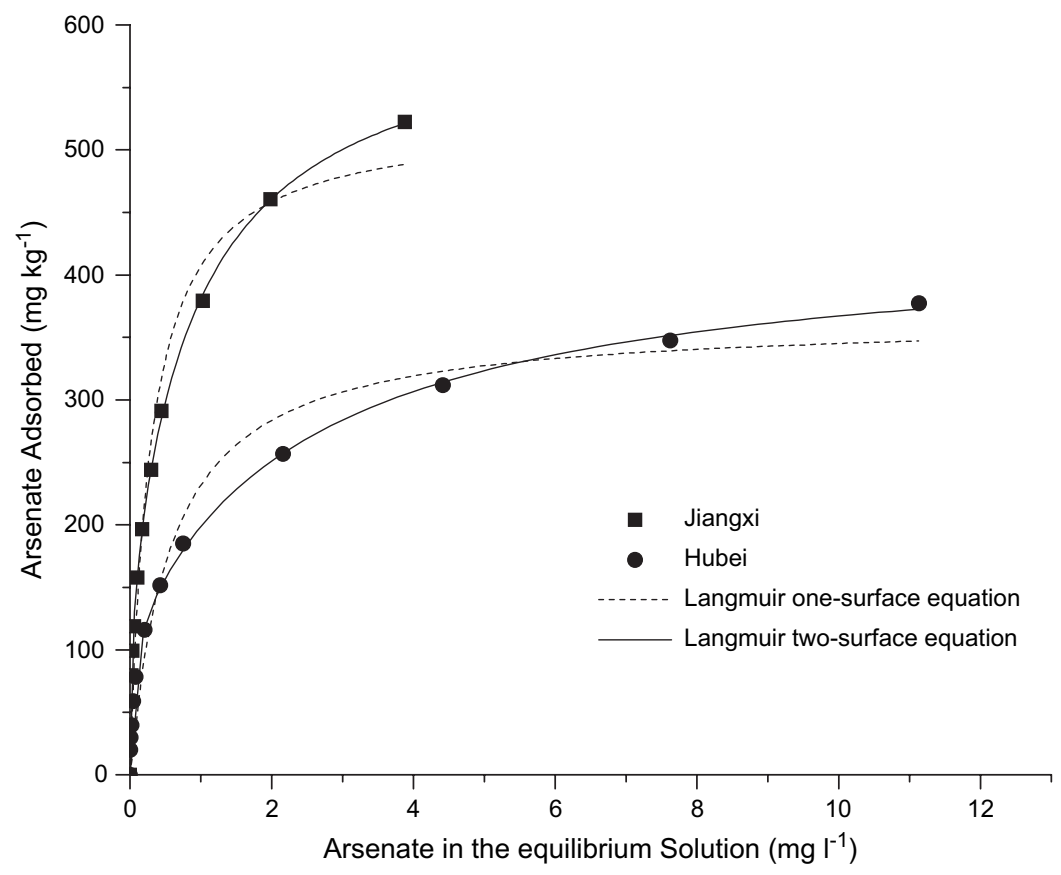

Fig. 2. Comparison of the Langmuir one-surface (----) and Langmuir two-surface equations ( - ) for fitting to the adsorption of arsenate by Jiangxi ) and Hubei soils (O) 
DOC or extractable P contents, the Langmuir two-surface equation better described arsenate adsorption by soils.

\section{Acknowledgements}

This work was funded by National Basic Research Program (2003CB415004), Chinese Academy of Sciences (grant No. KZCX3-SW-431) and National Natural Science Foundation of China (No. 20377049 and No. 20237010).

\section{References}

Anderson, M.A., Ferguson, J.F., Gavis, J., 1975. Arsenate adsorption on amorphous aluminium hydroxide. Journal of Colloid and Interface Science 54, 391-399.

Day, P.R., 1965. Particle fractionation and particle-size analysis. In: Black, C.A. (Ed.), Methods of Soil Analysis, Part 1. American Society of Agronomy, Inc., Madison, WI, USA, pp. 545-567.

Fendorf, S., Eick, M.J., Grossl, P., Sparks, D.L., 1997. Arsenate and chromate retention mechanisms on goethite 1 . Surface structure. Environmental Science and Technology 31, 315-320.

Fontes, M.R., Weed, S.B., Bowen, L.H., 1992. Association of microcrystalline goethite and humic acid in some oxisols from Brazil. Soil Science Society of America Journal 56, 982-990.

Frost, R.R., Griffin, R.A., 1977. Effect of pH on adsorption of arsenic and selenium from landfill leachate by clay minerals. Soil Science Society of America Journal 41, 53-57.

Goldberg, S., Glaubig, R.A., 1988. Anion sorption on calcareous montmorillonitic soil - arsenic. Soil Science Society of America Journal 52, 1297-1300.

Gu, B., Schmitt, J., Chen, Z., Liang, L., McCarthy, J.F., 1994. Adsorption and desorption of natural organic matter on iron oxide: mechanisms and models. Environmental Science and Technology 28, 38-46.

Harter, R.D., Naidu, R., 2001. An assessment of environmental and solution parameter impact on trace-metal sorption by soils. Soil Science Society of America Journal 65, 597-612.

Holford, I.C.R., Wedderburn, R.W.M., Mattingly, G.E.G., 1974. A Langmuir two-surface equation as a model for phosphate adsorption by soils. Journal of Soil Science 25, 242-255.

Holford, I.C.R., Mattingly, G.E.G., 1976. A model for the behaviour of labile phosphate in soil. Plant and Soil 44, 219-229.
Loeppert, R.L., Inskeep, W.P., 1996. Iron. In: Sparks, D.L., et al. (Eds.), Methods of Soil Analysis, Part 3: Chemical Methods. Soil Science Society of America, Inc., Madison, WI, USA, pp. 639-664.

Mandal, B.K., Suzuki, K.T., 2002. Arsenic round the world: a review. Talanta 58, 201-235.

Manning, B.A., Goldberg, S., 1997. Arsenic (III) and arsenic (V) adsorption on three California soils. Soil Science 162, 886-895.

Mead, J.A., 1981. A comparison of the Langmuir, Freundlich and Temkin equations to describe phosphate adsorption properties of soils. Australian Journal of Soil Research 19, 333-342.

Melamed, R., Jurinak, J.J., Dudley, L.M., 1995. Effect of adsorbed phosphate on transport of arsenate through an oxisol. Soil Science Society of America Journal 60, 121-131.

Nelson, D.W., Sommers, L.E., 1982. Total carbon, organic carbon, and organic matter. In: Page, A.L. (Ed.), Methods of Soil Analysis, Part 2. Chemical and Microbiological Properties, second ed. American Society of Agronomy, Madison, WI, USA, pp. 539-579.

Olsen, S.R., Cole, C.V., Watatanable, F.S., Dean, L.A., 1954. Estimation of available phosphorus in soils by extraction with sodium bicarbonate. USDA Circ 939. US Govt. Print Office, Washington, DC.

Oscarson, D.W., Huang, P.M., Hammer, U.T., Liaw, W.K., 1983. Oxidation and sorption of arsenite by manganese dioxide as influenced by surface coatings of iron and aluminium oxides and calcium carbonate. Water, Air and Soil Pollution 20, 233-244.

Pierce, M.L., Moore, C.B., 1982. Adsorption of arsenite and arsenate on amorphous iron hydroxide. Water Research 16, 1247-1253.

Rhoades, J.D., 1982. Cation-exchange capacity. In: Page, A.L. (Ed.), Methods of Soil Analysis, Part 2. Chemical and Microbiological Properties, second ed. American Society of Agronomy, Madison, WI, USA, pp. 149.

Smith, E., Naidu, R., Alston, A.M., 2002. Chemistry of inorganic arsenic in soils: II. Effect of phosphorus, sodium, and calcium on arsenic sorption. Journal of Environmental Quality 31, 557-563.

Sui, Y.B., Thompson, M.L., 2000. Phosphorus sorption, desorption, and buffering capacity in a biosolids-amended mollisol. Soil Science Society of America Journal 64, 164-169.

Syers, J.K., Browman, M.G., Smillie, G.W., Corey, R.B., 1973. Phosphate sorption by soils evaluated by the Langmuir adsorption equation. Soil Science Society of America Proceedings 37, 358-363.

Violante, A., Pigna, M., 2002. Competitive sorption of arsenate and phosphate on different clay minerals and soils. Soil Science Society of America Journal 66, 1788-1796.

$\mathrm{Xu}$, H., Allard, B., Grimvall, A., 1991. Effects of acidification and natural organic materials on the mobility of arsenic in the environment. Water, Air and Soil Pollution 57-58, 269-278. 